\title{
Sequence of interleukin $1 \beta$ actions on corpus luteum regression: relationship with inducible cyclooxygenase and nitric oxide synthase expression
}

\author{
A. Estevez, T. Tognetti, C. G. Luchetti, V. Sander and A. B. Motta* \\ Centro de Estudios Farmacológicos y Botánicos (CEFYBO) - Consejo de Investigaciones Científicas y \\ Técnicas (CONICET), Serrano 669 CP (1414), Buenos Aires, Argentina
}

Corpus luteum regression has been described in terms of: (i) functional luteolysis - a reversible decline in serum progesterone concentration; and (ii) structural luteolysis irreversible morphological changes and tissue remodelling events within the cellular membrane. In rats, $\mathrm{PGF}_{2 \alpha}$ and interleukin $1 \beta$ (IL-1 $\beta$ ) are involved in structural luteolysis, $\mathrm{PGF}_{2 \alpha}$ by increasing ovarian lipid peroxidation, and IL-1 $\beta$ by reducing progesterone and increasing PGF $_{2 \alpha}$ concentrations. The aim of the present report was to determine whether by an early action IL-1 $\beta$ is able to regulate functional luteolysis. Thus, ovarian explants from rats at the mid-stage of corpus luteum development were incubated during short periods with either 15 or 25 ng IL$1 \beta \mathrm{ml}^{-1}$. At $15 \mathrm{ng} \mathrm{ml}^{-1}$, IL-1 $\beta$ inhibited progesterone after
4 and $8 \mathrm{~h}$ of culture without affecting $\mathrm{PGF}_{2 \alpha}$ production, and a longer incubation ( $21 \mathrm{~h})$ was needed to increase $\mathrm{PGF}_{2 \alpha}$ production. In contrast, IL-1 $\beta$ enhanced $\mathrm{PGF}_{2 \alpha}$ concentrations at $8 \mathrm{~h}$ only at the higher dose (25 $\mathrm{ng}$ $\mathrm{ml}^{-1}$ ). The observed reduction in progesterone synthesis at the lower dose of IL-1 $\beta$ before the increase in $\mathrm{PGF}_{2 \alpha}$ concentrations led to the hypothesis that IL-1 $\beta$ regulates functional luteolysis (progesterone diminution) before it affects structural luteolysis $\left(\mathrm{PGF}_{2 \alpha}\right.$ increase). The fact that the early IL-1 $\beta$ action was described at $4 \mathrm{~h}$ but no effects on inducible nitric oxide synthase and inducible cyclooxygenase expression were found before this time led to the suggestion that these inductions were not necessary for the early IL-1 $\beta$ action described.

\section{Introduction}

Luteal regression or luteolysis, a mechanism widely studied for its implication in early pregnancy dysfunction, is an example of a decrease in cell function, which is a normal and necessary event in the mammalian reproductive cycle. The demise of the corpus luteum has been described as a decline in serum progesterone concentrations (functional luteolysis) followed by morphological changes and tissue remodelling events within the luteal tissue (structural luteolysis) (Duncan, 2000).

Immune cells, a very important source of cytokines, are present as normal components of the corpus luteum in many species and have been implicated as key regulators of the lifespan of the corpus luteum (Pate and Landis Keyes, 2001). The interleukin 1 (IL-1) system has been identified in the ovary of several species, including humans (Devoto et al., 2000) and rats (Wang et al., 1997; Kol et al., 1999), and performs a prominent role during follicular development and ovulation. Although IL-1 $\beta$ is present and influences ovarian physiology, there have been controversial results concerning its action.

${ }^{*}$ Correspondence

Email: aliciabmotta@yahoo.com.ar
Prostaglandins play a very important role in corpus luteum function. $\mathrm{PGF}_{2 \alpha}$ is well known for its luteolytic action (McCracken et al., 1999) and can be produced by the corpora lutea of many species. Many intracellular mechanisms are involved in this action: for example, the decrease of progesterone synthesis after administration of $\mathrm{PGF}_{2 \alpha}$ in vivo, reduction in the amount of sterol carrier protein, depletion of antioxidants from the corpus luteum and changes in the membrane fluidity of luteal cells. This last observation indicates that $\mathrm{PGF}_{2 \alpha}$ is an important regulator of structural luteolysis (Niswender et al., 2000).

Cyclooxygenase (COX) is the rate-limiting enzyme in the conversion of arachidonic acid to prostanoids. There are two COX isoforms: constitutive COX (COX I) and inducible COX (COX II) and they are responsible for the synthesis of prostanoids. COX II is highly induced during cell activation by various factors, including mitogens, hormones and cytokines (Nakao, et al., 2000). Prostaglandins and IL-1 $\beta$ system are strongly related: IL$1 \beta$ was found to induce expression of prostaglandin receptors, to inhibit cyclooxygenase-2 mRNA degradation (Narko et al., 1997) and to participate in the apoptotic mechanism.

Nitric oxide (NO) has been recognized as a paracrine molecule that evokes cell function via gas diffusion, a 
new concept in cell to cell signalling (Moncada and Higgs, 1993). NO participates in a variety of pathophysiological processes such as endothelium-derived relaxation of smooth muscle cells, inflammation and neurotransmission. In the female genital tract, $\mathrm{NO}$ is involved in regulating a wide variety of processes, including cervical ripening (Thomson et al., 1997), oviduct motility and ovarian processes such as ovulation (Ekerhovd et al., 1997). In previous studies of the mechanism of corpus luteum regression, oxytocin was shown to increase ovarian $\mathrm{PGF}_{2 \alpha}$ production during the late phase of corpus luteum development in rats (Motta et al., 1996). This action was mediated by enhancing ovarian NOS activity (Motta and Gimeno, 1997). Endogenous $\mathrm{NO}$ increased $\mathrm{PGF}_{2 \alpha}$ synthesis during structural luteolysis (Motta et al., 1999) and increased lipid peroxidation (Motta et al., 2001). IL-1 $\beta$ (1-25 ng $\mathrm{ml}^{-1}$ ) was also found to diminish, in a dose-dependent manner, progesterone production by ovarian dispersates from rats in the mid-luteal phase of corpus luteum development cultured for $21 \mathrm{~h}$ but to increase $\mathrm{PGF}_{2 \alpha}$ synthesis at the highest dose of IL-1 $\beta$ tested $\left(25 \mathrm{ng} \mathrm{m}^{-1}\right)$ (Estevez et al., 2002). A cyclooxygenase inhibitor was used to demonstrate that only at the highest IL-1 $\beta$ dose used could PGF $_{2 \alpha}$ act as an intermediary metabolite of IL-1 $\beta$ actions leading to the increase of ovarian lipid peroxidation and so participating in the structural luteolysis (Motta et al., 2001). This previous data did not reveal whether IL-1 $\beta$ could participate in functional luteolysis by means of an early action or the exact sequence of the longer lasting actions of IL-1 $\beta$. Therefore, the present study was designed with a shorter incubation time (1-8 h) in addition to the incubation used previously $(21 \mathrm{~h})$. Ovarian explants were incubated with either 15 or $25 \mathrm{ng} \mathrm{IL}-1 \beta \mathrm{ml}^{-1}$ and the functionality of the corpus luteum was evaluated by measuring progesterone and PGF $_{2 \alpha}$ contents. Previous studies (Motta and Gimeno, 1997) and the inflammatory characteristics of the process (prostaglandin concentrations, macrophage infiltration) indicated the value of studying the effect of IL-1 $\beta$ in the expression of the inducible isoforms of the two mainly ovarian enzymes involved (COX II and inducible nitric oxide synthase: iNOS).

\section{Materials and Methods}

\section{Animals}

The animal model used was that described by Motta et al. (1996). Briefly, immature (28-30 days of age) female rats of the Wistar strain were injected i.p. with $15 \mathrm{iu}$ equine chorionic gonadotrophin (pregnant mare's serum gonadotropin; Sigma Chemical Co., St Louis, MO) per rat. Day 0 of pseudopregnancy was considered to be $48 \mathrm{~h}$ after injection. This procedure induced formation of corpus luteum that remained functional for $9 \pm 1$ days. Three different stages of corpus luteum development can be established on the basis of serum progesterone concentrations: early, mid- and late luteolysis. In the present study, ovarian tissue from rats in the mid-stage of corpus luteum development (that is, those with the highest progesterone concentrations) were used. Rats were housed under conditions of controlled temperature $\left(22^{\circ} \mathrm{C}\right)$ and illumination $(14 \mathrm{~h}$ light: $10 \mathrm{~h}$ dark; lights on at 05:00 h) and allowed free access to Purina rat chow and water ad libitum. Animals were anaesthetized with ether and killed by cervical dislocation. Ovarian tissues from rats at the mid-stage of corpus luteum development were used.

The animal protocol used was conducted in accordance with the NIH Guide for the Care and Use of Laboratory Animals.

\section{Ovarian cultures}

Culture of ovarian tissue was performed as described by Motta et al. (2001). Briefly, tissues were removed, placed in a Petri plaque containing sterile Dulbecco's PBS and cut into quarters. These quarters were then distributed randomly and evenly at four explants per well in a 24-well culture plate (Nunc Multidish, Frederick, MD). Ovarian explants were then cultured in serum-free medium (M-199 medium: Sigma Chemical Co.). Ovarian IL-1 concentrations had been measured previously during corpus luteum development and cytokine concentrations were found to increase during luteolysis (data not shown). Therefore, IL-1 $\beta$ was added to the incubation media at 15 or $25 \mathrm{ng}$ $\mathrm{ml}^{-1}$. Incubations were carried out for $1,4,8$ or $21 \mathrm{~h}$ at $37^{\circ} \mathrm{C}$ in a humidified atmosphere of $50 \% \mathrm{O}_{2}: 5 \%$ $\mathrm{CO}_{2}$ to determine the temporal relationship between IL-1 $\beta$ treatment and both iNOS and COX II expression and, concomitantly, ovarian progesterone and $\mathrm{PGF}_{2 \alpha}$ production. Separate aliquots of culture media were collected for progesterone and $\mathrm{PGF}_{2 \alpha}$ determinations. Histological assays were made in cultured ovarian tissue to control tissue integrity.

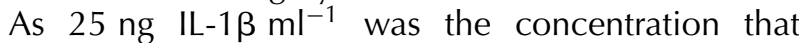
affected both progesterone and $\mathrm{PGF}_{2 \alpha}$ concentrations, this dose was used in immunoblot assays to study iNOS and COX II expression.

\section{Progesterone determination}

Incubation medium for hormone analysis was collected and frozen until progesterone concentration was determined by radioimmunoassay. The progesterone antiserum was provided by G. D. Niswender (Colorado State University, Fort Collins, CL); crossreactivity was $<2.0 \%$ for 20 - $\alpha$-dihydro-progesterone and deoxycorticosterone and $<1.0 \%$ for other steroids normally in the serum. The sensitivity of the assay was 5-10 pg per tube. Results are expressed as pg per mg tissue. 
Prostaglandin $F_{2 \alpha}$ determination in cell culture media

$\mathrm{PGF}_{2 \alpha}$ concentrations were measured by radioimmunoassay. A rabbit antiserum (Sigma Chemical Co.) was used to evaluate the concentration of $\mathrm{PGF}_{2 \alpha}$ in culture media. Sensitivity of the assay was 5-10 $\mathrm{pg} \mathrm{ml}^{-1}$ and the crossreactivity was $<0.1 \%$ for $\mathrm{PGE}_{1}$ and $\mathrm{PGE}_{2}$. Results are expressed as pg per $\mathrm{mg}$ tissue.

\section{Histological assay}

Rat ovarian sections $(4-6 \mu \mathrm{m})$ were fixed immediately in $4 \%(\mathrm{v} / \mathrm{v})$ paraformaldehyde and stained with haematoxylin and eosin (DAKO Corporation, Carpinteria, CA) for histological analysis to confirm the integrity of the tissues after the different incubation periods and treatments.

\section{Western blot analysis for NOS and COX}

Western blot analysis of ovarian homogenates was performed according to the procedure described by Jablonka-Shariff and Olson (1997) to study possible changes in protein concentrations during the different incubation periods (1, 4, 8 and $21 \mathrm{~h}$ ). Briefly, frozen rat ovaries were placed in $370 \mu \mathrm{l}$ ice-cold homogenization buffer ( 1 mmol EDTA I-1 $0.1 \%$ TX-100 with the addition of $1 \mu \mathrm{g}$ aprotinin $\mathrm{ml}^{-1}, 10 \mu \mathrm{g}$ leupeptin $\mathrm{ml}^{-1}, 1 \mathrm{mg}$ benzamidine $\mathrm{ml}^{-1}$ and $200 \mu \mathrm{g}$ soybean trypsin inhibitor $\mathrm{ml}^{-1}$ ), homogenized on ice and centrifuged at $6000 \mathrm{~g}$ for $10 \mathrm{~min}$ at $4^{\circ} \mathrm{C}$. Equal amounts of protein $(60 \mu \mathrm{g})$ from homogenized ovaries were diluted in SDS sample buffer and heated at $95^{\circ} \mathrm{C}$ for $4 \mathrm{~min}$. Samples were loaded on to $4.0-7.5 \%$ (for NOS), $4.0-12 \%$ (for COX) gradient SDS-PAGE gels and separated by electrophoresis for $2 \mathrm{~h}$ at constant current $(25 \mathrm{~mA})$. Rainbow-coloured protein molecular mass markers (7.5-200 kDa) were always run on each gel together with the corresponding positive controls. Separated proteins were electrotransferred on to nitrocellulose membranes (Sigma Chemical Co.) using a mini electrophoretic transfer cell (Bio-Rad Laboratories, Hercules, CA) at $4{ }^{\circ} \mathrm{C}$ overnight at constant voltage (40 V) in a buffer containing 20\% methanol, $25 \mathrm{mmol}$ Tris $\mathrm{I}^{-1}, 192 \mathrm{mmol}$ glycine $\mathrm{I}^{-1}$, and $0.02 \%$ SDS. Membranes were washed in $0.1 \%(\mathrm{v} / \mathrm{v})$ Tween 20 in a solution of $100 \mathrm{mmol} \mathrm{NaCl} \mathrm{I}^{-1}$ and $10 \mathrm{mmol}$ Tris I $\mathrm{I}^{-1}$ at $\mathrm{pH} 7.5$ (T-TBS) and incubated in blocking buffer (5\% BSA in T-TBS) for $1 \mathrm{~h} 30 \mathrm{~min}$ at room temperature with gentle agitation. The presence of iNOS or COX II was confirmed by incubating the membranes with iNOS or COX II polyclonal murine antibody (Cayman Chemical, Ann Arbor, MI) at a dilution of 1:1000. After they were washed, membranes were incubated with an alkaline phosphatase-conjugated anti-rabbit IgG (1:5000) for $1 \mathrm{~h}$ at room temperature. Finally, the iNOS and COX II were detected in the membranes after incubating with the

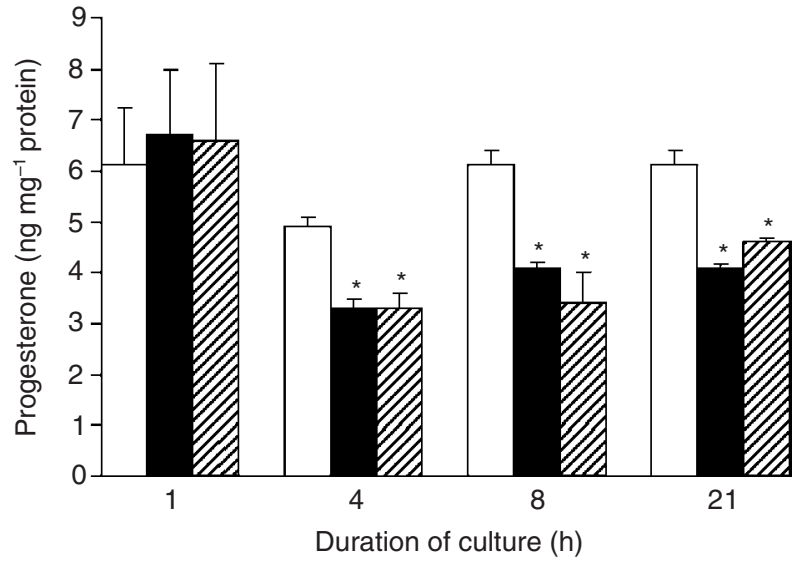

Fig. 1. Effect of interleukin $1 \beta(\mathrm{IL}-1 \beta)\left(15(\mathbf{\square})\right.$ or $\left.25(\square) \mathrm{ng} \mathrm{ml} \mathrm{m}^{-1}\right)$ on progesterone production by rat ovarian tissue in culture. Each group represents the mean \pm SEM of 10 different animals. Experiments were carried out in duplicate. ${ }^{*} P<0.05,{ }^{*} P<0.01$ significantly different compared with controls $(\square)$.

alkaline phosphatase substrate BCIP-NBT (Sigma Chemical Co.). The relative amounts of iNOS or COX II were quantified by densitometric scanning of the membranes using Sigma Gel Software in each group (controls and treated). Positive controls for COX and iNOS included homogenates of lipopolysaccharide (LPS)-activated AW 264.7 macrophages. The proper loading was evaluated by staining the membranes with Ponceau-S.

\section{Statistical analyses}

Statistical analyses were carried out using the Instat program (GraphPAD software, San Diego, CA). Analysis of variance and Student-Newman-Keuls test were used for comparisons between values of groups $(P<0.05$ was considered to be significant).

\section{Results}

\section{Effect of IL-1 $\beta$ on ovarian progesterone production}

$\mathrm{IL}-1 \beta$ treatment (15 or $25 \mathrm{ng} \mathrm{ml}^{-1}$ ) had no effect on ovarian progesterone concentrations after $1 \mathrm{~h}$ of incubation, but at 4, 8 and 21 h of culture, both 15 and $25 \mathrm{ng} \mathrm{IL}-1 \beta \mathrm{ml}^{-1}$ significantly diminished progesterone production compared with controls (Fig. 1).

\section{Effect of IL-1 $\beta$ on ovarian $P G F_{2 \alpha}$ production}

As for the progesterone assay, IL-1 $\beta$ had no effect at $1 \mathrm{~h}$ of culture (Fig. 2). In contrast to progesterone, only

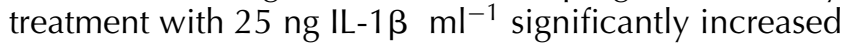
$\mathrm{PGF}_{2 \alpha}$ production at 4 and $8 \mathrm{~h}$ (Fig. 2). Only after $21 \mathrm{~h}$ 


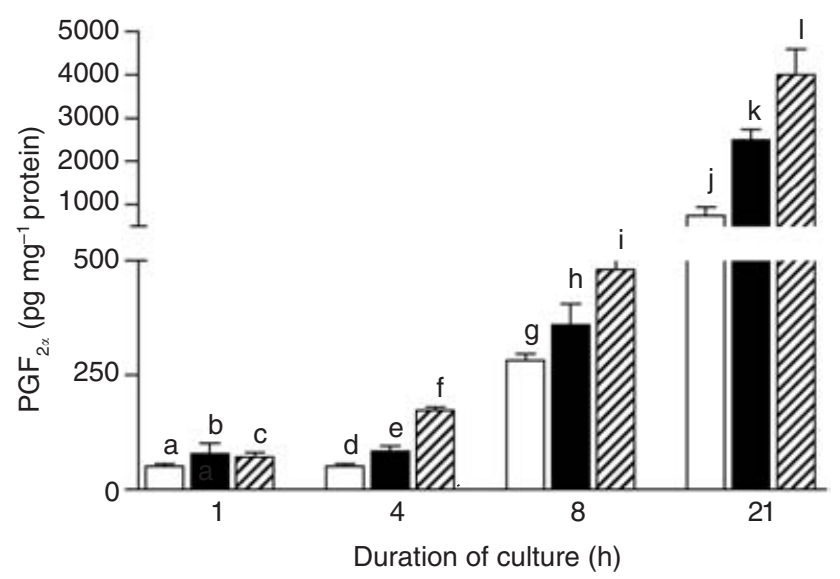

Fig. 2. Effect of interleukin $1 \beta(\mathrm{IL}-1 \beta)\left(15(\mathbf{\square})\right.$ or $\left.25(\rrbracket) \mathrm{ng} \mathrm{ml} \mathrm{m}^{-1}\right)$ on $\mathrm{PGF}_{2 \alpha}$ production by rat ovarian tissue in culture. Experiments were carried out in duplicate. d versus f; g versus i; j versus k; j versus $\mathrm{l}$; $\mathrm{a}, \mathrm{d}$ versus $\mathrm{g}$; $\mathrm{a}, \mathrm{d}$ versus $\mathrm{j}$ : significantly different from controls ( $\square): P<0.05$.

of incubation were both 15 and $25 \mathrm{ng}$ IL- $1 \beta \mathrm{ml}^{-1}$ treatments able to increase $\mathrm{PGF}_{2 \alpha}$ production (Fig. 2). It is important to note that basal $\mathrm{PGF}_{2 \alpha}$ output increased at 8 and $21 \mathrm{~h}$ of incubation time (Fig. 2: a,d versus $\mathrm{g}$ and $\mathrm{a}, \mathrm{d}$ versus $\mathrm{j}$ ) probably as a result of the increase in this prostanoid transport as has been reported by Jawerbaum et al. (2000).

\section{Effect of IL-1 $\beta$ on the expression of iNOS by ovarian rat tissue}

Explants were cultured for $1,4,8$ or $21 \mathrm{~h}$ with or without the IL-1 $\beta$ (treated and control, respectively; Fig. 3) to determine the temporal relationship between IL-1 $\beta$ and iNOS expression. The IL-1 $\beta$ dose that modified both progesterone and $\mathrm{PGF}_{2 \alpha}$ concentrations (25 ng $\mathrm{ml}^{-1}$ ) was used. Inducible NOS was detected in samples at $130 \mathrm{KDa}$.

IL-1 $\beta$ treatment had no effect on iNOS expression after $1 \mathrm{~h}$ of incubation but promoted ovarian expression after $4 \mathrm{~h}$ of treatment (Fig. 3). IL-1 $\beta$ treatment was able to increase iNOS expression at $8 \mathrm{~h}$ (Fig. 3) but had no effect at $21 \mathrm{~h}$ (Fig. 3).

\section{Effect of IL-1 $\beta$ on the expression of COX II by ovarian rat tissue}

Ovarian explants were cultured for $1,4,8$ or $21 \mathrm{~h}$ with and without $25 \mathrm{ng} \mathrm{IL}-1 \beta \mathrm{ml}^{-1}$ to examine the possible regulation of COX II expression. Inducible COX was detected in samples at $72 \mathrm{KDa}$. IL-1 $\beta$ treatment $\left(25 \mathrm{ng} \mathrm{ml}^{-1}\right.$ ) had no effect on COX II expression at $1 \mathrm{~h}$ of incubation, increased expression after $4 \mathrm{~h}$ (Fig. 4) and $8 \mathrm{~h}$ (Fig. 4) but did not modify COX II expression at $21 \mathrm{~h}$ of culture (Fig. 4).
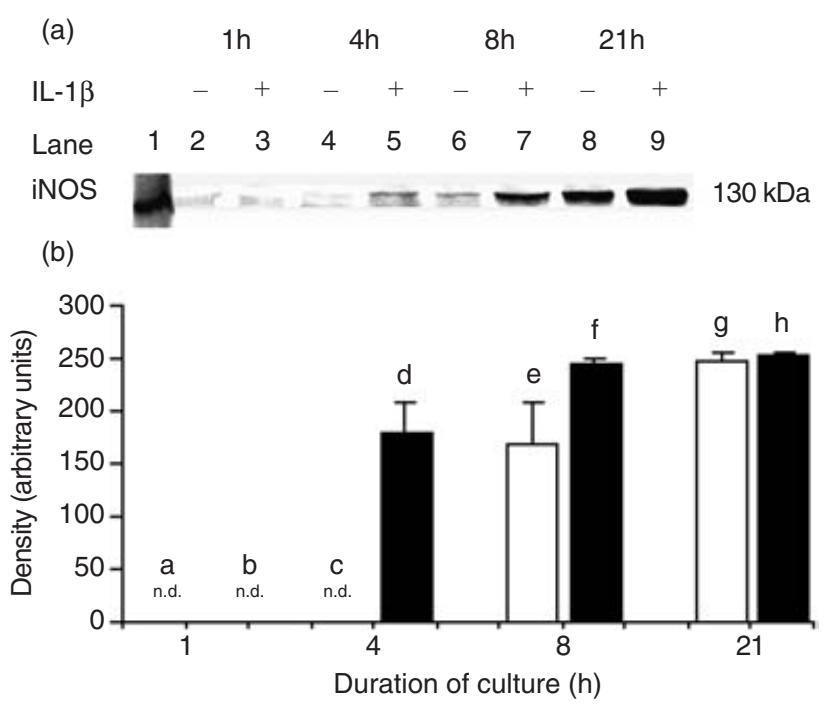

Fig. 3. Effect of interleukin $1 \beta$ (IL-1 $\beta$ ) (ם) on the inducible nitric oxide synthase (iNOS) by rat ovarian tissue. (a) Lane 1: positive control lipopolysaccharide (LPS)/AW 264.7 macrophages. Lanes 2, 4, 6 and 8: basal ovarian iNOS expressions. Lanes 3, 5, 7 and 9: IL-1 $\beta$-treated ovarian iNOS expressions. Experiments were carried out in duplicate $(n=8)$. (b) Semiquantitative analysis of ovarian iNOS expression after IL-1 $\beta$ treatment. Density represents the area:intensity ratio. Two experiments were carried out and the data were analysed by Student-Newman-Keuls test. The proper loading was evaluated by staining the membranes with Ponceau-S. n.d: not detected. Significant differences compared with controls ( $\square$ ): e versus g: $P<0.05$; c versus d: $P<0.001$; e versus f: $P<$ 0.05 ; g versus h: $P>0.05$.

\section{Discussion}

A growing body of evidence indicates the mammalian ovary may be a site of IL-1 $\beta$ production (Brannstrom and Norman, 1993), reception (Scherzer et al., 1996) and action (Towson and Pate, 1994). A putative regulator of ovulation and luteal function (Brannstrom and Norman, 1993), IL-1 $\beta$ has been observed to modulate the functional and morphological differentiation of cultured mouse, pig and human granulosa cells (Narko et al., 1997; Matsubara et al., 2000). In spite of this, the exact mechanism(s) by which luteal function is regulated remains unknown.

Study of the mechanism involved in the corpus luteum regression has revealed that IL-1 $\beta$ uses the NO pathway to inhibit progesterone production concomitantly with $\mathrm{PGF}_{2 \alpha}$ induction (Estevez et al., 2002). Considering that luteolysis occurs as a result of multiple and complex interactions, and that previous studies were limited to one time $(21 \mathrm{~h})$, a temporal study was designed to investigate the exact sequence in the pathway that involves IL-1 $\beta, \mathrm{PGF}_{2 \alpha}$ and $\mathrm{NO}$ in the demise of the corpus luteum. Ovarian explants from rats in the midstage (functional) of corpus luteum development were cultured for different times $(1,4,8$ or $21 \mathrm{~h})$ with 15 and $25 \mathrm{ng} \mathrm{IL-} 1 \beta \mathrm{ml}^{-1}$. 
The fact that both doses of IL-1 $\beta$ were able to inhibit ovarian progesterone concentrations after as little as $4 \mathrm{~h}$ of incubation was in agreement with the findings of Townson and Pate (1994) that, at $4 \mathrm{~h}$, IL$1 \beta$ inhibits progesterone concentrations of bovine luteal cells, excluding the detrimental effects of inhibitors of the cellular mechanisms of IL-1 $\beta$ action. After longer incubation ( 8 or $21 \mathrm{~h}$ ) IL-1 $\beta$ also inhibited progesterone and this action was consistent with other mechanisms in which IL-1 $\beta$ is involved but needs more time for its action, such as the ovulation process (Peterson et al., 1993), fertilization outcome (Mendoza et al., 2002), modulating steroidogenic acute regulatory protein (StAR) in endometriotic stromal human cells (Tsai et al., 2001) and inhibiting oestrogen production in human granulosa-luteal cells from women undergoing in vitro fertilization (Tobai and Nishiya, 2001).

However, only the higher dose of IL-1 $\beta$ increased $\mathrm{PGF}_{2 \alpha}$ production when ovarian explants were incubated at 4 or $8 \mathrm{~h}$. In accordance with previous findings, treatment with either 15 or $25 \mathrm{ng} \mathrm{IL-} 1 \beta \mathrm{ml}^{-1}$ increased ovarian $\mathrm{PGF}_{2 \alpha}$ production when cultures were carried out for $21 \mathrm{~h}$ (Estevez et al., 2002). With respect to the increase in basal ovarian $\mathrm{PGF}_{2 \alpha}$ production for up to $8 \mathrm{~h}$ of incubation, an enhanced release of prostanoids into the incubation media has been reported previously from the present authors' laboratory in other tissues (Franchi et al., 1989; Jawerbaum et al., 2000). xs

The fact that the actions of IL-1 $\beta$ on progesterone and $\mathrm{PGF}_{2 \alpha}$ Occurred after shorter periods ( 4 and $8 \mathrm{~h}$ ) indicates either a regulation of $\mathrm{PGF}_{2 \alpha}$ receptor expression (Narko et al., 1997) or a direct effect on key enzymes of steroidogenic pathway (Donesky et al., 1998) by the cytokine could be abolished, as longer times have been reported for both events. It is important to point out that nuclear factor $\kappa \mathrm{B}(\mathrm{NF} \kappa \mathrm{B})$ has been recognized as a key second messenger in rapid actions of cytokines; Zamorano et al. (2001) demonstrated that both IL-4 and tumour necrosis factor $\alpha$ were able to enhance the activation of NFKB in a myeloid parental cell line after as little as $4 \mathrm{~h}$ of incubation. In addition, Kwon et al. (2001) described a synergistic IL-1 $\beta$ activation of NFKB pathway early at $2 \mathrm{~h}$ in human alveolar epithelial cells and Takahashi et al. (2001) reported that IL-1 $\beta$ activated NFKB and subsequently induced COX II in gastric fibroblast. Therefore, it is possible that in the system used in the present study, IL-1 $\beta$ is using the NFKB activation for a rapid action. Assays are being conducted to confirm this observation.

The fact that ovarian progesterone concentrations were decreased with the lower dose of IL-1 $\beta$ and that a higher concentration or a longer IL-1 $\beta$ exposure were needed to increase ovarian $\mathrm{PGF}_{2 \alpha}$ production led to the suggestion that IL-1 $\beta$ modulates functional luteolysis before it affects structural luteolysis.

The NO system has been involved in the actions of IL-1 $\beta$ in ovarian rats (Ahsan et al., 1997) but the exact

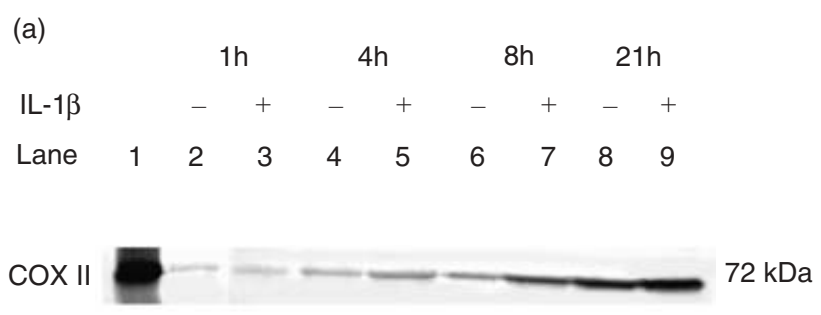

(b)

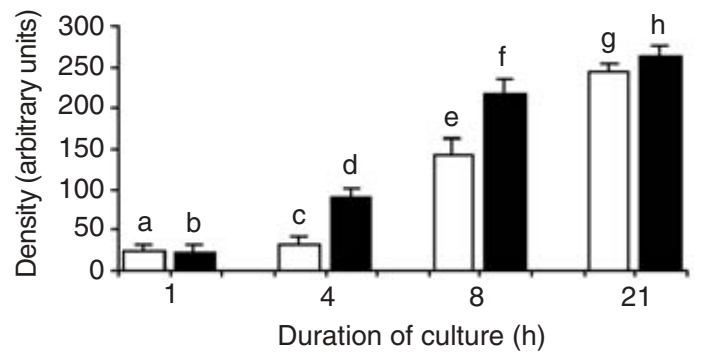

Fig. 4. Effect of interleukin $1 \beta$ (IL-1 $\beta$ ) on the inducible cyclooxygenase (COX II) by rat ovarian tissue. (a) Lane 1: positive control lipopolysaccharide (LPS)/AW 264.7 macrophages. Lanes 2, 4, 6 and 8: basal ovarian COX II expression. Lanes 3, 5, 7 and 9: IL$1 \beta$-treated ovarian COX II expression. Each group represents the mean \pm SEM of ten different animals. Experiments were carried out in duplicate $(n=8)$. (b) Analysis of ovarian COX II expression after IL-1 $\beta$ treatment $(\mathbf{\square})$. Density represents the area:intensity ratio. Two experiments were carried out and the data were analysed by Student-Newman-Keuls test. The proper loading was evaluated by staining the membranes with Ponceau-S. Significance of differences compared with controls ( $\square$ ): a versus c: $P>0.05$; c versus e: $P<$ 0.001; e versus g: $P<0.001$; c versus d: $P<0.05$; e versus f: $P<$ 0.001 ; g versus h: $P>0.05$.

sequence of this mechanism remains unknown. In the present study, the pattern of expression of both inducible isoforms of the main enzymes involved in the pathway investigated (iNOS and COX II) were analysed. Under basal conditions, ovarian iNOS expression was present in cultures at 8 and $21 \mathrm{~h}$ of incubation. IL-1 $\beta$ promoted the expression of the enzyme after only $4 \mathrm{~h}$ incubation, while maintaining the iNOS band density at 8 and $21 \mathrm{~h}$.

The analysis of COX II expression showed that ovarian explants were able to express the enzyme early, after $1 \mathrm{~h}$ incubation. Treatment with IL-1 $\beta\left(25 \mathrm{ng} \mathrm{ml}^{-1}\right)$ was able to enhance COX II expression when it was added to cultures carried out at 4 and $8 \mathrm{~h}$ incubation.

The above data indicate that, at first, IL-1 $\beta$ reduces ovarian progesterone production by means of a mechanism independent of COX II or iNOS protein induction, as the expression of COX II and iNOS were not increased or induced by the cytokine before its early action. When cultures were carried out for longer than $4 \mathrm{~h}$, the induction of COX II and iNOS expression by IL-1 $\beta$ may amplify the mechanism increasing ovarian $\mathrm{PGF}_{2 \alpha}$ concentrations and leading to the structural luteolysis. Cross-talk between inducible iNOS and COX II has been reported in rat chondrocytes (Boileau et al., 2002) and 
in primary hippocampal neuronal culture (Serou et al., 1999).

In summary, a rapid effect of IL-1 $\beta$ on rat ovarian progesterone synthesis by a mechanism(s) independent of iNOS and COX II protein induction is proposed. Later action by IL-1 $\beta$ induces iNOS and COX II proteins, increasing $\mathrm{PGF}_{2 \alpha}$ ovarian synthesis.

The authors thank S. Zorz and C. Pokrant for reviewing this manuscript. This work was supported by Programa Latinoamericano de Capacitación e Investigación en Reproducción Humana (PLACIRH) - Re-entry Grant RE 049/2001 and Ministerio de Salud (beca Ramon Carrillo-Arturo Oñativia, referencia 0143).

\section{References}

Ahsan S, Lacey M and Whitehead SA (1997) Interactions between interleukin- $1 \beta$ nitric oxide and prostaglandin $E_{2}$ in the rat ovary: effects on steroidogenesis European Journal of Endocrinology 137293 300

Boileau C, Martel-Pelletier J, Moldovan F, Jouzeau JY, Netter P, Marnning PT and Pelletier JP (2002) The in situ upregulation of chondrocyte interleukin-1-converting enzyme and interleukin-1 $\beta$ levels in experimental osteoarthritis is mediated by nitric oxide Arthritis and Rheumatism 46 2637-2647

Brannstrom M and Norman RJ (1993) Involvement of leukocytes and cytokines in the ovulatory process and corpus luteum function Human Reproduction 8 1762-1775

Devoto L, Vega M, Kohen P, Castro A, Castro O, Christenson LK, Carvallo $\mathbf{P}$ and Strauss JF (2000) Endocrine and paracrine-autocrine regulation of the human corpus luteum during the mid-luteal phase Journal of Reproduction and Fertility Supplement 55 13-20

Donesky BW, Días de Moura M, Tedeschi C, Hurwitz A, Adashi EY and Payne DW (1998) Interleukin-1 $\beta$ inhibits steroidogenic bioactivity in cultured rat ovarian granulosa cells by stimulation of progesterone degradation and inhibition of estrogen formation Biology of Reproduction $\mathbf{5 8} 1108-1116$

Duncan WC (2000) The human corpus luteum: remodelling during luteolysis and maternal recognition of pregnancy Reviews of Reproduction $\mathbf{5}$ $12-17$

Ekerhovd E, Brannstrom M, Alexandersson M and Norstrom, A (1997) Evidence for nitric oxide mediation of contractile activity in isolated of the human Fallopian tube Human Reproduction 12301 305

Estevez A, Tognetti T, Rearte MB, Sander V and Motta AB (2002) Interleukin$1 \beta$ in the functional and structural luteolysis. Relationship with the nitric oxide system Prostaglandins, Leukotrienes and Essential Fatty Acids 67 $411-417$

Franchi AM, Gimeno MA and Gimeno L (1989) Factors subserving the enhancing effect of progesterone on the output of prostaglandin $F_{2 \alpha}$ in uteri from ovariectomized rats Prostaglandins, Leukotrienes and Essential Fatty Acids 35 113-118

Jablonka-Shariff A and Olson L (1997) Hormonal regulation of nitric oxide synthases and their cell-specific expression during follicular development in the rat ovary Endocrinology 138 460-468

Jawerbaum A, Gonzalez ET, Sinner D, Pustovrh C, White V and Gimeno M (2000) Diminished $\mathrm{PGE}_{2}$ content, enhanced $\mathrm{PGE}_{2}$ release and defects in ${ }^{3} \mathrm{H}_{-} \mathrm{PGE}_{2}$ transport in embryos from overtly diabetic rats Reproduction, Fertility and Development 12 141-147

Kol S, Donesky BW, Ruutiainen-Altman K, Ben-Shlomo I, Irahara M, Ando M, Rohan RM and Adashi EY (1999) Ovarian interleukin-1 receptor antagonist in rats: gene expression, cellular localization, cyclic variation, and hormonal regulation of a potential determinant of interleukin-1 action Biology of Reproduction 61 274-282
Kwon S, Newcomb RL and George SC (2001) Mechanism of synergistic cytokine-induced nitric oxide production in human alveolar epithelial cells Nitric Oxide 5 534-546

McCracken JA, Custer EE and Lamsa CJ (1999) Luteolysis: a neuroendocrine-mediated event Physiological Reviews 79 263-323

Matsubara H, Ikuta K, Ozaki Y, Suzuki Y, Sato T and Suzumori K (2000) Gonadotropins and cytokines affect luteal function through control of apoptosis in human luteinized granulosa cells Journal of Clinical Endocrinology and Metabolism 4 1620-1626

Mendoza C, Ruiz-Requena E, Ortega E, Cremades N, Martinez F, Bernabeu R, Greco E and Tesarik J (2002) Follicular fluid markers of oocyte developmental potential Human Reproduction 17 1017-1022

Moncada S and Higgs A (1993) The arginine-nitric oxide pathway New England Journal of Medicine 329 2002-2012

Motta AB and Gimeno MAF (1997) Nitric oxide participates in the corpus luteum regression in ovaries isolated from pseudopregnant rats Canadian Journal of Physiology and Pharmacology 75 13351339

Motta AB, Franchi AM, Faletti AG and Gimeno MAF (1996) Effect of an oxytocin receptor antagonist in ovarian and uterine synthesis and release of prostaglandin $\mathrm{F}_{2 \alpha}$ in pseudopregnant rats Prostaglandins, Leukotrienes and Essential Fatty Acids 54 95-100

Motta AB, Estévez A and Gimeno MAF (1999) The involvement of nitric oxide in corpus luteum regression in the rat: feedback mechanism between prostagladin $\mathrm{F}_{2 \alpha}$ and nitric oxide Molecular Human Reproduction 5 1011-1016

Motta AB, Estévez A, Franchi A, Perez-Martinez S, Farina M, Ribeiro ML, Lasserre A and Gimeno MAF (2001) Regulation of lipid peroxidation by nitric oxide and $\mathrm{PGF}_{2 \alpha}$ during luteal regression in rats Reproduction 121 631-637

Nakao S, Ogata NS, Shimizu-Sasaki E, Yamazaki M, Furuyama $S$ and Sugiya H (2000) Activation of NFKB is necessary for IL-1 $\beta$-induced cyclooxygenase-2 (COX-2) expression in human gingival fibroblasts Molecular and Cellular Biochemistry 209 113-118

Narko K, Ritvos O and Ristmaki A (1997) Induction of cyclooxygenase2 and prostaglandin $F_{2 \alpha}$ receptor expression by interleukin-1 $\beta$ in cultured human granulosa-luteal cells Endocrinology 138 36383644

Niswender GD, Juengel JL, Silva PJ, Rollyson MK and McIntush EW (2000) Mechanisms controlling the function and the lifespan of the corpus luteum Physiological Reviews 80 1-29

Pate JL and Landis Keyes P (2001) Immune cells in the corpus luteum: friends or foes Reproduction 122 665-676

Peterson CM, Hales HA, Hatasaka HH, Mitchell MD, Rittenhouse L and Jones KP (1993) Interleukin-1 $\beta$ (IL-1 $\beta$ ) modulates prostaglandin production and the natural IL-1 receptor antagonist inhibits ovulation in the optimally stimulated rat ovarian perfusion model Endocrinology 133 2301-2306

Scherzer WJ, Ruutiainen-Altman KS, Putowski LT, Kol S, Adashi EY and Rohan RM (1996) Detection and in vivo hormonal regulation of rat ovarian type I and type II interleukin-1 receptor mRNA: increased expression during the periovulatory period Journal of the Society for Gynecologic Investigation 3 131-140

Serou MJ, De Coster MA and Bazan NG (1999) Interleukin-1 $\beta$ activates expression of cyclooxygenase-2 and inducible nitric oxide synthase in primary hippocampal neuronal culture: platelet-activating factor as a preferential mediator of cyxlooxygenase expression Journal of Neuroscience Research 58 593-598

Takahashi S, Fujita T and Yamamoto A (2001) Role of nuclear factor$\mathrm{\kappa B}$ in gastric ulcer healing in rats American Journal of Physiology Gastrointestinal and Liver Physiology 280 1296-1304

Thomson AJ, Lunan BC, Cameron AD, Cameron IT, Greer IA and Norman JE (1997) Nitric oxide donors induce ripening of the human uterine cervix: a randomised controlled trial British Journal of Obstetrics and Gynaecology 104 1054-1057

Tobai H and Nishiya I (2001) Nitric oxide mediates inhibitory effect of interleukin- $1 \beta$ on estrogen production in human granulosa-luteal cells Journal of Obstetrics and Gynaecology Research 27 5359 
Townson DH and Pate JL (1994) Regulation of prostaglandin synthesis by interleukin-1 in cultured bovine luteal cells Biology of Reproduction 51 480-485

Tsai SJ, Wu HH, Liu CC, Sun HS and Chen HM (2001) Regulation of steroidogenic acute regulatory protein expression and progesterone in endothelial stromal cells Journal of Clinical Endocrinology and Metabolism 86 5765-5763

Wang C, Branstrom M, Cui KH, Simula AP, Hart RP, Maddocks S and Norman RJ (1997) Localization of mRNA for interleukin-1 receptor and interleukin-1 receptor antagonist in the rat ovary Journal of Endocrinology 152 11-17
Zamorano J, Mora AL, Boothby M and Keegan AD (2001) NF-кB activation plays an important role in the IL-4-induced protection from apoptosis International Immunology 12 1479-1487

Received 3 February 2003.

First decision 8 April 2003.

Resubmitted manuscript received 4 June 2003.

Accepted 4 August 2003. 